\title{
LAMINOPLASTY AND CORPECTOMY IN THE TREATMENT OF CERVICAL SPONDYLOTIC MYELOPATHY
}

\author{
LAMINOPLASTIA E CORPORECTOMIA NO TRATAMENTO DA MIELOPATIA \\ ESPONDICOLOGICA CERVICAL
}

\author{
LAMINOPLASTIA Y CORPECTOMÍA EN EL TRATAMIENTO DE LA MIELOPATÍA \\ ESPONDILÓTICA CERVICAL
}

\begin{abstract}
Dreval' Maxim Dmitrievich ${ }^{1}$, Arestov Sergey Olegovich'1 ${ }^{1}$ Petrosyan David Vazgenovich ${ }^{1}$, Kashcheev Alexey Alexeevich ${ }^{1}$ Vershinin Andrey Vyacheslavovich'1, Poltorako Ekaterina Nikolaevna', Gushcha Artem Olegovich ${ }^{1}$
\end{abstract}

1. Federal State Research Institution Research Center of Neurology, Department of Neurosurgery, Moscow, Russia

\begin{abstract}
Introduction: Cervical Spondylotic myelopathy (CSM) is a disabling manifestation of extended cervical stenosis characterized by pronounced neurological dysfunction. Decompressive interventions contribute to significant regression of symptoms and, in some cases, complete recovery can be achieved. Objective: To explore the potential of laminoplasty in patients with extended cervical spondylotic stenoses complicated by myelopathy, and to develop approaches for surgical intervention in these patients. Methods: Fifty-six patients were included in the study. Laminoplasty was performed in 34 patients. Corpectomy was performed in 22 patients who made up the comparison group. The frequency and initial severity of concomitant non-neurological disorders in both groups were comparable. Results: Indications for laminoplasty were determined. They include: symptoms of spondylotic myelopathy, three or more levels of compression, preservation of lordosis, absence of signs of segmental instability, inability to perform anterior decompression, and age over 55 years. The presence of signs of segmental instability, kyphotic deformation, and history of mental disorders may be considered as contraindications for this surgery. Conclusions: Due to a number of advantages, laminoplasty is the treatment of choice for extended cervical spondylotic stenosis. Adequate selection of patients based on the evaluation of clinical symptoms, extension of stenosis, neurological signs and neuroimaging features enable excellent results to be achieved. Level of Evidence: II. Type of Study: Prospective comparative study.
\end{abstract}

Keywords: Myelitis; Laminoplasty; Spinal fusion; Spinal stenosis.

\section{RESUMO}

Introdução: A mielopatia espondilótica cervical (MSC) é uma manifestação incapacitante de estenose cervical extensa, caracterizada por disfunção neurológica pronunciada. As intervenções descompressivas contribuem para a regressão significativa dos sintomas e, em alguns casos, a recuperação completa pode ser alcançada. Objetivo: Explorar o potencial da laminoplastia em pacientes com estenoses espondilóticas cervicais extensas complicadas por mielopatia e desenvolver abordagens para intervenção cirúrgica nesses pacientes. Métodos: 56 pacientes foram incluídos no estudo. A laminoplastia foi realizada em 34 pacientes. A corpectomia foi realizada em 22 pacientes, que compuseram o grupo de comparação. A frequência e a gravidade inicial dos distúrbios não neurológicos concomitantes em ambos os grupos foram comparáveis. Resultados: As indicações para laminoplastia foram determinadas. Eles incluem: sintomas de mielopatia espondilótica, três ou mais níveis de compressão, presenvação da lordose, ausência de sinais de instabilidade segmentar, incapacidade de realizar descompressão anterior e idade superior a 55 anos. A presença de sinais de instabilidade segmentar, deformação cifótica e história de transtornos mentais podem ser considerados como contraindicações para essa cirurgia. Conclusões: Devido a uma série de vantagens, a laminoplastia é o tratamento de escolha para estenose espondilótica cervical estendida. A seleção adequada dos pacientes, com base na avaliação dos sintomas clínicos, extensão da estenose, sinais neurológicos e características de neuroimagem, possibilitam alcançar excelentes resultados. Nível de Evidência: II . Tipo de Estudo: Estudo Comparativo prospectivo.

Descritores: Mielite; Laminoplastia; Fusão vertebral; Estenose espinal.

\section{RESUMEN}

Introducción: La mielopatía espondilótica cervical (MSC) es una manifestación incapacitante de estenosis cervical extendida caracterizada por una fuerte disfunción neurológica. Las intervenciones de descompresión contribuyen a la regresión significativa de los síntomas y, en algunos casos, se puede lograr una recuperación completa. Objetivo: Explorar el potencial de la laminoplastia en pacientes con estenosis espondilótica cervical extendida complicada por mielopatía y desarrollar enfoques para la intervención quirúrgica en estos pacientes. Métodos: Cincuenta y seis pacientes fueron incluidos en el estudio. Laminoplastia se realizó en 34 pacientes. Corpectomía se realizó en 22 pacientes que componen el grupo de comparación. La frecuencia y la gravedad inicial de los trastornos no neurológicos concomitantes en ambos grupos fueron comparables. Resultados: Se determinaron las indicaciones para laminoplastia. Estas incluyen: síntomas de mielopatía espondilótica, tres o más niveles de compresión, preservación de la lordosis, ausencia de signos de inestabilidad segmentaria, incapacidad 
para realizar descompresión anterior y edad mayor de 55 años. La presencia de signos de inestabilidad segmentaria, deformación cifótica y antecedentes de trastornos mentales puede considerarse una contraindicación para esta cirugía. Conclusiones: Debido a una serie de ventajas, la laminoplastia es el tratamiento de elección para la estenosis espondilótica cenvical extendida. La adecuada selección de pacientes basada en la evaluación de los síntomas clínicos, la extensión de la estenosis, los signos neurológicos y las características de neuroimágenes hacen posible obtener excelentes resultados. Nivel de Evidencia: II Tipo de Estudio: Estudio comparativo prospectivo.

Descriptores: Mielitis; Laminoplastia; Fusión vertebral; Estenosis espinal.

\section{INTRODUCTION}

The treatment of degenerative spine diseases is urgent nowadays. This group of pathologies has many clinical manifestations and forms, and the average age of this group of patients is becoming steadily lower. Various manifestations of degenerative spine disease affect the working population aged 25-45 years. In developed countries $30 \%$ of the population is affected by back pain and about $70 \%$ of population visits a neurologist due to back pain at least once in their lifetime. ${ }^{1}$ According to Watkins et al., the lumbar spine is affected in the majority of cases (62\%), the cervical spine is involved less often (36\%), the degenerative disease of the thoracic spine is comparatively rare $(2 \%)^{2}$

Despite the high frequency of degenerative disease detection in cervical spine, defining its treatment tactics is still quite disputable. $^{3-5}$ A major question of surgical treatment of a single-level spine pathology is usually the choice of an implant, except in cases of lateral intervertebral disc hernias, which can be managed by an anterior uncoforaminotomy or endoscopic interlaminotomy. Even more questions arise in cases of extended cervical stenosis complicated by spondylogenic cervical myelopathy. The majority of the population aged $>55$ years have $x$-ray signs of cervical spinal canal stenosis, and a third of them have corresponding clinical and neurological manifestations. ${ }^{3}$ The decision to carry out surgery is often postponed until the formation of a persistent neurological impairment, due to the remissive nature of this disease. In a study of 120 patients, Clarke and Robinson analyzed the dynamics of its clinical progression: $50 \%$ of patients were stable and had no evident progression, $25 \%$ had progression tendency with remission periods, 20\% had neurological impairment with no remissions, and $5 \%$ had rapid progression. ${ }^{6}$ As Lees and Turner showed in 1963, patients who suffer from a spinal cord compression for more than ten years become disabled in the majority of cases. ${ }^{7}$

When it comes to choosing surgical treatment for extended cervical stenosis, surgeons are guided by the following rules: maximum decompression of the spinal cord and nerve roots with maximum preservation or reconstruction of the vertebral column, minimization of postoperative complications, and the shortest possible hospitalization time..$^{8-11}$

There are several surgical techniques for managing this pathology, most of which are performed via the anterior and posterior approaches. Despite their great popularity among neurosurgeons and orthopedists, anterior surgical approaches have several disadvantages (risk of recurrent laryngeal nerve and esophagus injury, pseudoarthrosis formation, adjacent level disease etc.). ${ }^{12,13}$ Laminectomy is probably the oldest surgical technique for managing the degenerative disease of cervical spine, and was originally used to treat cervical spine stenosis. In the mid-1980s, a series of articles appeared describing negative outcomes of laminectomy - axial pain, formation of kyphotic deformation, etc..$^{10,14-16}$

Laminoplasty is one of the posterior approaches used for spinal cord decompression in cases of cervical spondylosis, ossification of the posterior longitudinal ligament, intervertebral disc herniation, primary spinal stenosis, or a combination of the above. Cervical laminoplasty was initially described by Oyama in $1973 .{ }^{17}$ Since then, the original technique has undergone a number of improvements. There are about twenty different modifications of laminoplasty. Since its start, laminoplasty has been actively implemented and has defined its niche in the surgical treatment of cervical spondylotic myelopathy (CSM), although it has not received proper attention in various industrialized and developing countries. The mastery and popularization of laminoplasty techniques, and their active introduction into the practice of cervical stenosis treatment, will significantly increase the efficiency of surgery and reduce intraoperative trauma. $^{9-12,14}$

Objective: To assess the possibilities of laminoplasty surgery techniques and develop surgery tactics in patients with extended spondylogenic cervical stenosis complicated by myelopathy.

\section{METHODS}

This study included 56 patients with CSM. Laminoplasty was performed in 34 patients who were recruited between the end of 2011 and 2015. The median age was $59.4 \pm 12.8$ years, and the ratio of women and men was 9:25. Of the total, 28 patients had three levels of stenosis, four patients had four, and two patients had five. In the control group, 22 patients underwent corpectomy; these operations were performed between 2010 and 2011, the average age of the patients was $43.8 \pm 16.4$ years, and the ratio of women and men was $7: 15$. The frequency of comorbidities and their severity in the two groups were comparable $(p>0.05)$.

The clinical characteristics of the patients included in the study are shown in Table 1.

The collection of medical anamnesis and the neurological examination were performed independently by two specialists - a neurosurgeon and a neurologist. Assessment of the patients' clinical status was carried out using the following scales and questionnaires:

1. Modified scale of the Japanese Orthopedic Association (JOA score). 2. Scale of cervical myelopathy according to Nurick (Nurick grade). 3. Scale of evaluation of proprioceptive sensitivity (Doita, Sakai). ${ }^{18}$ 4. Visual analogue pain scale (VAS) in the postoperative period.

We used MRI (magnetic induction of at least 1.5 T) as a basic examination for all patients. Where necessary, neurophysiological methods (somatosensory evoked potential - SSEP, and transcranial magnetic stimulation - TMS) were used.

The study was approved by the local ethics committee of the FGBNU Scientific Center of Neurology, Moscow. Patients signed an informed consent form before being recruited into the study.

Statistical data were evaluated using the PASW Statistics 18 software. The significance level $(p)$ was assumed to be 0.05 for all the comparisons performed.

Table 1. Clinical presentations of cervical spondylotic myelopathy.

\begin{tabular}{c|c|c|c|c}
\hline \multirow{2}{*}{ Symptoms } & \multicolumn{2}{|c|}{$\begin{array}{c}\text { aminoplasty } \\
(\mathbf{n}=\mathbf{3 4 )}\end{array}$} & \multicolumn{2}{c}{$\begin{array}{c}\text { Corpectomy } \\
(\mathbf{n}=\mathbf{2 2})\end{array}$} \\
\cline { 2 - 5 } & $\mathbf{n}$ & $\%$ & $\mathbf{n}$ & $\%$ \\
\hline Upper paraparesis & 11 & $31.9 \%$ & 8 & $36 \%$ \\
\hline Tetraparesis & 17 & $49.3 \%$ & 13 & $59 \%$ \\
\hline Sensory disorders & 24 & $70.5 \%$ & 18 & $81 \%$ \\
\hline Bowel and bladder disorders & 2 & $5.8 \%$ & 1 & $4,5 \%$ \\
\hline Reflex abnormalities & 29 & 84.1 & 21 & $94,5 \%$ \\
\hline Gait disorders & 17 & 49.3 & 11 & $49,5 \%$ \\
\hline Muscle atrophy & 20 & $58.0 \%$ & 16 & $72 \%$ \\
\hline Combination of clinical symptoms & 34 & $100 \%$ & 22 & $100 \%$ \\
\hline
\end{tabular}




\section{Surgical technique and stages}

All operations were performed under general endotracheal anesthesia.

The initial stages of the operation are shown in Figure 1A. The importance of cutaneous incision and subperiosteal dissection (skeletization, Figure 1B, 1C) should be emphasized; these must be performed strictly by the middle line, which enables the muscle tissue to be preserved and minimizes blood loss, as well as reducing the further axial pain in the neck.

The next step is to perform a bilateral foraminotomy at the C4-C5 level. Foraminotomy is an addition to the main stage, and serves to prevent paresis of the muscles innervated by the roots of $\mathrm{C} 5$. In the lateral part of the $\mathrm{C} 4-\mathrm{C} 5$ arches, minimal bone resection is followed by a flavectomy and visualization of the roots of C5. Less than $25 \%$ of the facet joints is resected. The root ganglion can be visualized and revised by a hook at less than $20 \%$ joint resection. This nerve root decompression was sufficient, in our study, to achieve a good result (Figure 2A, 2B, 2C, 2D)

The next stage of the operation is to saw the vertebral arcs. This manipulation and the subsequent lifting of the posterior support complex is the most dangerous stage in terms of potential damage to the dura mater, as it involves mobilization of the dural sac, and risk of bleeding from the spasmodic lateral veins, etc. During the preoperative modeling, the sides of through and partial cuts of the vertebral arches are determined, depending on the neurological symptoms and localization of maximum compression, which are usually concordant. In cases where there is a discrepancy between the symptoms and radiological data, through-cuts are performed on the side with the most severe symptoms, and one- or multi-level foraminotomy is also performed on the side of stenosis (Figure 3A, 3B). In other cases, MRI and CT data are followed.

Bilateral sawing allows the arches to be lifted, increasing the angle to 30 or more degrees. The mobility of the complex is examined by dragging the spinous processes; in sites where the arch is not completely resected, palpation reveals an obstacle, usually occurring in the area of "tile" joint overlay. After bone perforation towards the cut lumen, a hemostatic gauze must be applied.

The step of raising and fixing the arches carries an increased risk of damaging the dura mater. It is very important to prevent an inner cortical layer fracture on the partial cut side when lifting the posterior complex (Figures 4A, 4B, 4C).

For the final fixation of the support complex, standard microplates for maxillofacial surgery and cranioplasty are used (Figures
$5 \mathrm{~A}, 5 \mathrm{~B}, 5 \mathrm{C})$. For a reliable fixation, screws with a depth of $6 \mathrm{~mm}$ are used. The thickness of the plate differs from 0.6 to $10 \mathrm{~mm}$ (a smaller plate thickness is not recommended because of the risk of fracture). In our experience, implementation of two or more screws in the joint and arch fixation reliably fixes the plate and practically excludes its fracture, if all the requirements are met in the postoperative period.

After assessing the mobility of the arch-spinous complex, the surgeon proceeds to modeling the microplate. The plate is modeled intraoperatively and individually for each patient. A plate that has been modeled more than three times is not recommended for installation due to metal fatigue. The modeled plate is initially fixed to the arcuate joint, then fixation is performed for the mobilized arch. It is important to fix the arch without using excessive force, i.e., it is not recommended fixing the arch in the position of maximum ascent angle (Figure 6A, 6B).

\section{RESULTS}

For the patients of the laminoplasty group, when assessing the severity of myelopathy using JOA scale in the preoperative period,

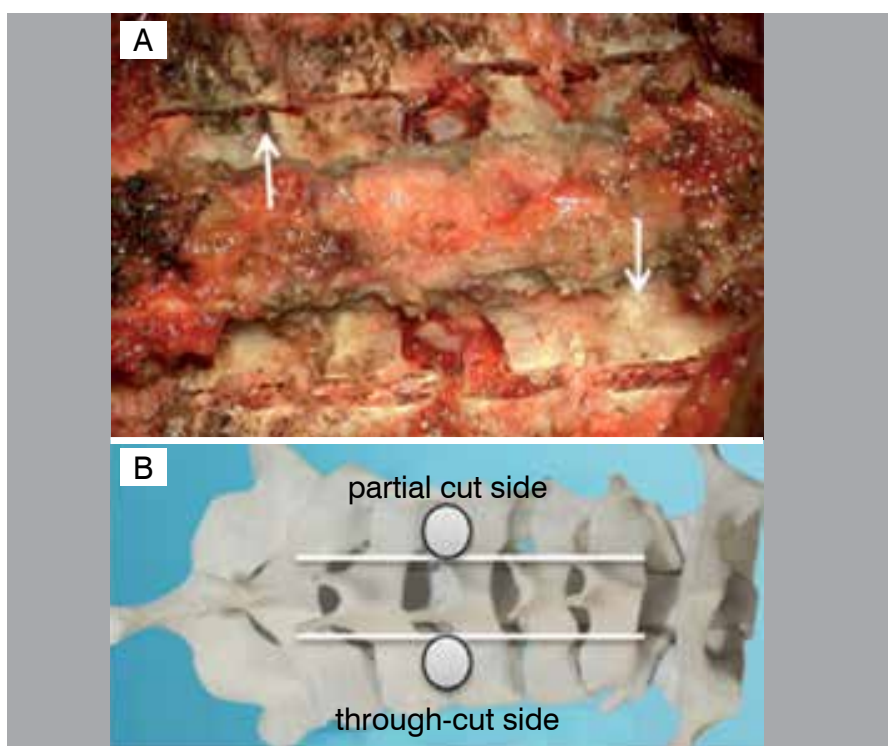

Figure 3. Sawn vertebral arches. A.Cutting of the vertebral arches at the level of stenosis; B. the plan of vertebral arch sawing.
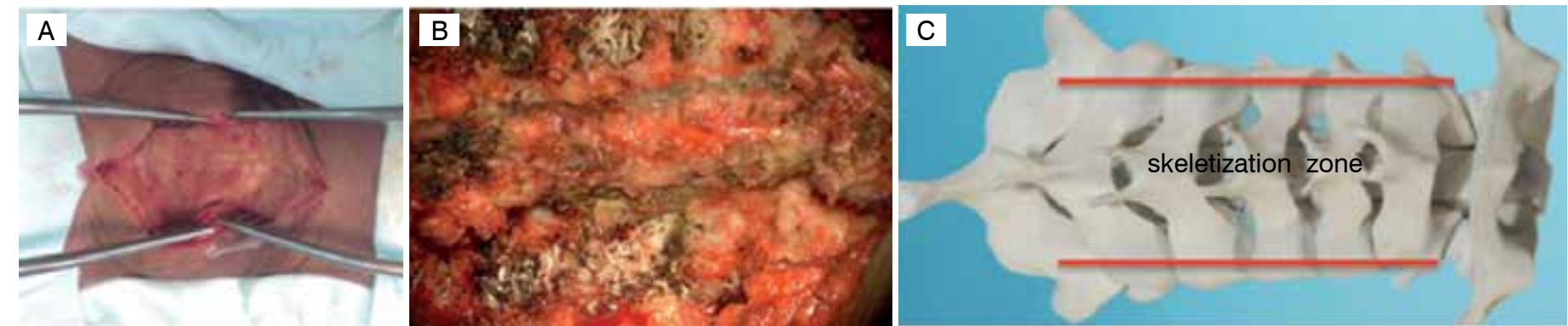

Figure 1. Initial stages of surgery. A. Skin Incision along the middle, bloodless line; B. the skeletization stage is completed; the medial edges of the vertebral arches and lateral parts of the arcuate joints are fully visualized; C. skeletization zone of the arcuate joints
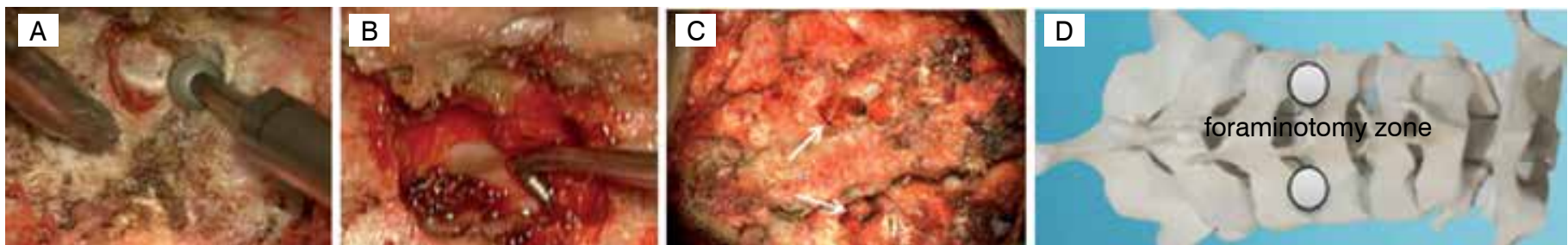

Figure 2. Foraminotomy. A. Use of a boron with a diamond nozzle; B. foraminotomy is carried out using a hook; the root is explored; C. bilateral foraminotomy is performed; D. zone of foraminal decompression. 

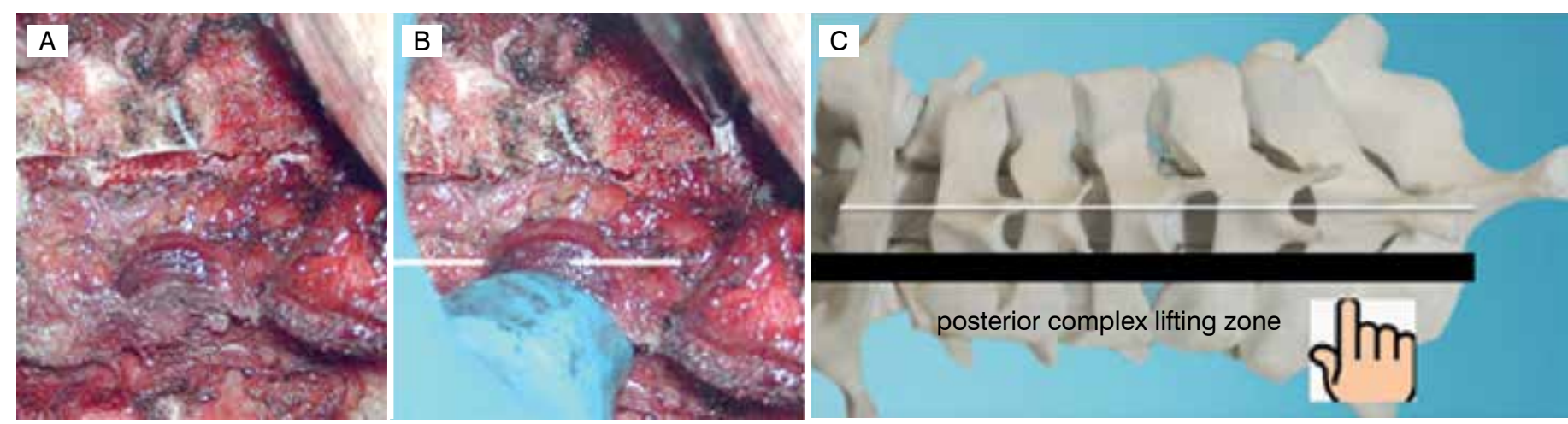

Figure 4. Raising/bringing the arches to the fixation position. A. Spinous processes: the bilateral arches are sawn; B. assessment of mobilization by abduction of the spinous process; C. zone of resection and elevation of the complex.

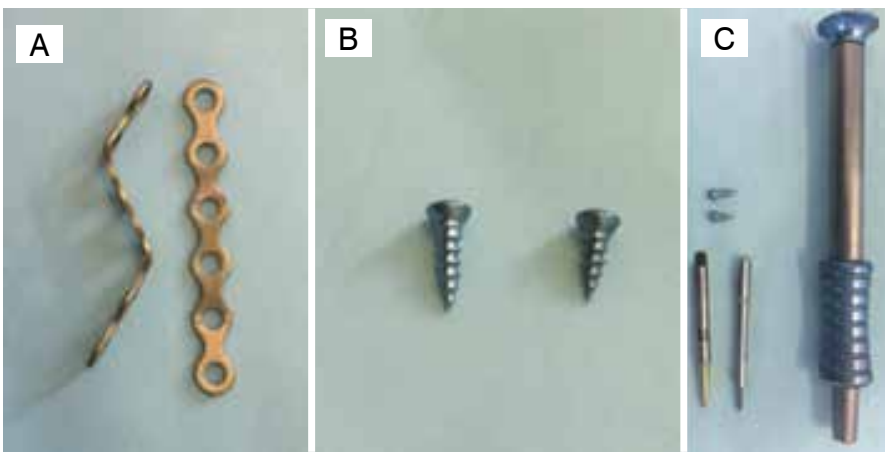

Figure 5. Fixation of the support complex. A. Modeled intraoperative plate; B. self-drilling screws, 6 and $5 \mathrm{~mm}$; C. a demountable screwdriver with two tips, one of which is a drill bit.
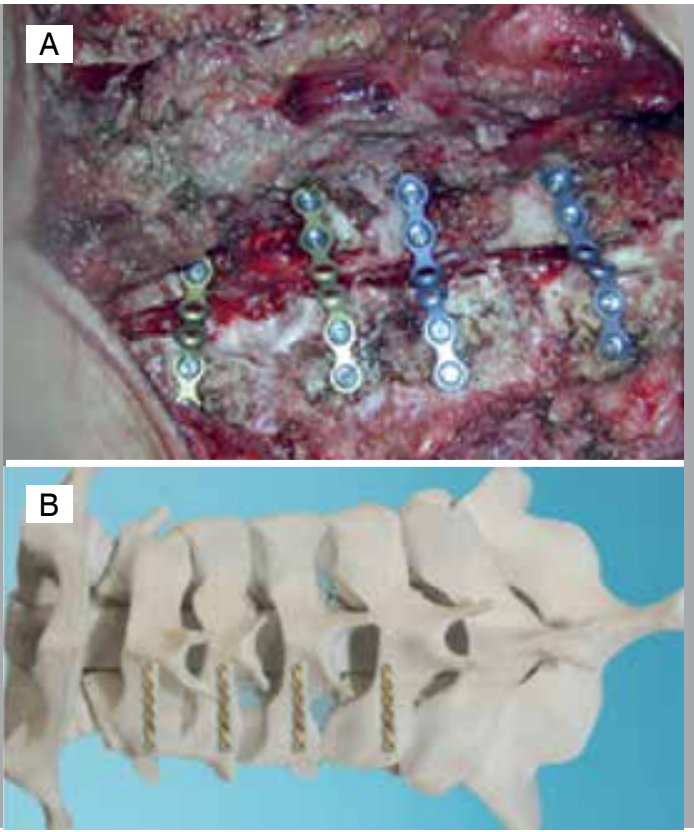

Figure 6. The final appearance of the wound. A. Laminoplasty on 4 levels; B. Vertebral arches fixed by implanted microplates.

the average result was $8.27 \pm 2.1$ points, which corresponds to severe myelopathy. The average score on the JOA scale 18-24 months after surgery was $11.18 \pm 1.6$. This shows a transition of myelopathy severity to the moderate level in this group. The average recovery rate was $28.2 \% \pm 11.3 \%$ in patients who had had clinical manifestations of more than 18 months, and $46.2 \% \pm 19.2 \%$ in patients with symptoms for less than 18 months $(p<0.05)$.
In the patients of the corpectomy group, the mean JOA score for myelopathy was $10 \pm 2.4$ in the preoperative period (moderate severity). The average JOA score 18-24 months after the operation was $15 \pm 1.2$. The average recovery rate was $44.7 \pm 16.4 \%$ in patients with symptoms lasting more than 18 months and $58.8 \pm$ $18.1 \%$ in patients with symptoms lasting less than 18 months.

Subgroups of patients with different preoperative clinical status and disease durations were compared, to assess the prognosis of neurological deficit recovery. The clinical presentation was assessed 24 months after laminoplasty and corpectomy. Patients were divided into two subgroups, depending on the duration of the disease: $>2$ years and $<2$ years (Table 2 ).

We analyzed the patients' status using the Nurick scale before and after laminoplasty, to evaluate the result of the operation in terms patient transition from one level of myelopathy severity to another (Table 3).

Table 4 shows the dynamics of proprioception and tactile sensitivity (Doita, Sakai scale) 6 months after laminoplasty. As the table shows, a number of patients had either a decrease in severity or normalization in terms of proprioception and tactile perception impairment. It is important to note that the patients we observed for more than 6 months did not experience any further significant improvement; these parameters should therefore be evaluated in the first 6 months.

This study demonstrates maximum efficacy of laminoplasty at moderate and severe stages of proprioception deterioration.

Table 2. Assessment of recovery according to the JOA scale in patients with myelopathy depending on the duration of the disease.

\begin{tabular}{c|c|c|c|c|c}
\hline \multicolumn{2}{|l|}{$\begin{array}{l}\text { Index on JOA scale } \\
\text { before laminoplasty }\end{array}$} & \multicolumn{2}{|c|}{$\begin{array}{c}\text { Index on JOA scale } \\
\text { after laminoplasty }\end{array}$} & \multicolumn{2}{c}{ Recovery factor (Kr) } \\
\hline $\begin{array}{c}\text { History } \\
>\mathbf{2} \text { years }\end{array}$ & $\begin{array}{c}\text { History } \\
<\mathbf{2} \text { years }\end{array}$ & $\begin{array}{c}\text { History } \\
>\mathbf{2} \text { years }\end{array}$ & $\begin{array}{c}\text { History } \\
<\mathbf{2} \text { years }\end{array}$ & $\begin{array}{c}\text { History } \\
>\mathbf{2} \text { years }\end{array}$ & $\begin{array}{c}\text { History } \\
<\mathbf{2} \text { years }\end{array}$ \\
\hline $8.27 \pm 1.4$ & $11.3 \pm 1.2$ & $11.18 \pm 2.4$ & $13.8 \pm 1.5$ & $28.2 \pm 11.3$ & $46.2 \pm 19.2$ \\
\hline $10 \pm 2.4$ & $12.4 \pm 1.5$ & $14.7 \pm 0.6$ & $15.4 \pm 1.5$ & $44.7 \pm 16.4$ & $58.8 \pm 18.1$ \\
\hline
\end{tabular}

Table 3. Pre- and postoperative neurological evaluation of the patients of the laminoplasty group.

\begin{tabular}{|c|c|c|}
\hline \multicolumn{2}{|c|}{$\begin{array}{c}\text { Nurick grade before } \\
\text { laminoplasty }\end{array}$} & \multirow{2}{*}{$\begin{array}{c}\text { Nurick grade after laminoplasty } \\
6 \text { patients }(17.7 \%):+3 \text { patients } \\
\text { from grade } 2\end{array}$} \\
\hline Grade 1 & 3 patients $(8.8 \%)$ & \\
\hline Grade 2 & 7 patients $(20.6 \%)$ & $\begin{array}{l}9 \text { patients }(26.5 \%):+5 \text { patients from } \\
\text { grade } 3 \text {, transition of } 3 \text { patients to grade } 1\end{array}$ \\
\hline Grade 3 & 18 patients $(52.9 \%)$ & $\begin{array}{c}16 \text { patients }(47 \%):+3 \text { patients from grade } \\
4 \text {, transition of } 5 \text { patients to grade } 2\end{array}$ \\
\hline Grade 4 & 4 patients $(11.8 \%)$ & $\begin{array}{l}1 \text { patient }(2.9 \%):+1 \text { patient from grade } \\
5, \text { transition of } 3 \text { patients to grade } 3, \\
\text { transition of } 1 \text { patient to grade } 5\end{array}$ \\
\hline Grade 5 & 2 patients (5.9\%) & $\begin{array}{c}2 \text { patients }(5.9 \%):+1 \text { patient from grade } 4, \\
\text { transition of } 1 \text { patient to grade } 4\end{array}$ \\
\hline
\end{tabular}


The incidence of complications was almost identical in two groups of patients, as shown in Table 5.

The final assessment criterion was the severity of the neck pain by VAS. As Table 6 shows, in the corpectomy group, cervical axial pains in the early postoperative period were slightly milder compared to laminoplasty group, which is explained by a more rigid fixation performed by the anterior approach. Residual pain in the neck after laminoplasty is associated with intraoperative damage to the posterior neck muscles and extensive bone resection (innervation of the periosteum); restriction of the movements in the cervical spine for 1.5-2 months after the operation is another reason, in our opinion.

\section{DISCUSSION}

In the present study, we conducted the first systematic comparison of laminoplasty and corpectomy results in surgical treatment of CSM in Russia.

Table 4. Pre- and postoperative evaluation of proprioception and light touch sensation (Doita, Sakai scale) ${ }^{18}$ in the laminoplasty group.

\begin{tabular}{|c|c|c|c|c|}
\hline \multicolumn{3}{|c|}{ Proprioception ( $\mathrm{n}=34$ ) } & \multicolumn{2}{|c|}{ Light touch ( $n=34$ ) } \\
\hline \multirow{2}{*}{$\begin{array}{l}\text { Grade } 0 \\
\text { (normal) }\end{array}$} & $\begin{array}{l}\text { before } \\
\text { surgery }\end{array}$ & $\begin{array}{c}6 \text { months after } \\
\text { surgery }\end{array}$ & $\begin{array}{l}\text { before } \\
\text { surgery }\end{array}$ & $\begin{array}{c}6 \text { months after } \\
\text { surgery }\end{array}$ \\
\hline & $\begin{array}{c}3 \text { patients } \\
(8.8 \%)\end{array}$ & $\begin{array}{c}9 \text { patients }(26.5 \%) \text { : } \\
+6 \text { patients from } \\
\text { grade } 1\end{array}$ & $\begin{array}{c}2 \text { patients } \\
(5.9 \%)\end{array}$ & $\begin{array}{c}8 \text { patients }(23.5 \%) \text { : } \\
+6 \text { patients from } \\
\text { grade } 1\end{array}$ \\
\hline Grade 1 & $\begin{array}{c}18 \\
\text { patients } \\
(52.9 \%)\end{array}$ & $\begin{array}{c}16 \text { patients }(47 \%):+4 \\
\text { patients from grade } \\
2, \text { transition of } 6 \\
\text { patients to grade } 0\end{array}$ & $\begin{array}{c}14 \\
\text { patients } \\
(41.2 \%)\end{array}$ & $\begin{array}{c}13 \text { patients }(38 \%):+5 \\
\text { patients from stage } \\
2, \text { transition of } 6 \\
\text { patients to grade } 0\end{array}$ \\
\hline Grade 2 & $\begin{array}{c}9 \text { patients } \\
(26.5 \%)\end{array}$ & 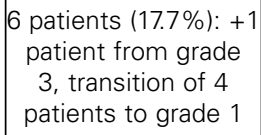 & $\begin{array}{c}15 \\
\text { patients } \\
(44 \%)\end{array}$ & $\begin{array}{c}11 \text { patients }(32 \%):+1 \\
\text { patient from grade } \\
3, \text { transition of } 5 \\
\text { patients to grade } 1\end{array}$ \\
\hline Grade 3 & $\begin{array}{c}4 \text { patients } \\
(11.8 \%)\end{array}$ & $\begin{array}{c}3 \text { patients }(8.8 \%) \text { : } \\
\text { transition of } 1 \text { patient } \\
\text { to grade } 2\end{array}$ & $\begin{array}{c}3 \text { patients } \\
(8.8 \%)\end{array}$ & $\begin{array}{c}2 \text { patients }(5.8 \%) \text { : } \\
\text { transition of } 1 \text { patient } \\
\text { to grade } 2\end{array}$ \\
\hline
\end{tabular}

Table 5. Early and delayed complications.

\begin{tabular}{c|c|c|c}
\hline Complications & $\begin{array}{c}\text { Laminoplasty } \\
(\mathbf{n}=\mathbf{3 4 )}\end{array}$ & $\begin{array}{c}\text { Corpectomy } \\
\mathbf{( n = 2 2 )}\end{array}$ & Outcome \\
\hline Transient C5 palsy & $3(8.8 \%)$ & $0(0 \%)$ & $\begin{array}{c}\text { Full regress until } \\
\text { discharge }\end{array}$ \\
\hline Revision intervention & $2(5.9 \%)$ & $2(9.1 \%)$ & $\begin{array}{c}\text { Postoperative } \\
\text { hematoma, failure of } \\
\text { decompression }\end{array}$ \\
\hline Kyphotic deformation & $1(2.9 \%)$ & $2(9.1 \%)$ & $\begin{array}{c}\text { kinesiotherapy, } \\
\text { rehabilitation }\end{array}$ \\
\hline $\begin{array}{c}\text { Severe proprioception } \\
\text { deterioration }\end{array}$ & $1(2.9 \%)$ & $1(4.5 \%)$ & $\begin{array}{c}\text { Active postoperative } \\
\text { rehabilitation, } \\
\text { unchanged }\end{array}$ \\
\hline $\begin{array}{c}\text { Adjacent level } \\
\text { syndrome }\end{array}$ & $1(2.9 \%)$ & $3(13.6 \%)$ & $\begin{array}{c}\text { Surveillance, } \\
\text { rehabilitation }\end{array}$ \\
\hline
\end{tabular}

Table 6. Dynamics of cervicalgia (VAS score).

\begin{tabular}{c|c|c|c|c|c}
\hline $\begin{array}{c}\text { Cervicalgia } \\
\text { before } \\
\text { laminoplasty }\end{array}$ & \multicolumn{2}{|c|}{$\begin{array}{c}\text { Cervicalgia after } \\
\text { laminoplasty }\end{array}$} & \multicolumn{2}{c|}{$\begin{array}{c}\text { Cervicalgia } \\
\text { before } \\
\text { corpectomy }\end{array}$} & \multicolumn{2}{|c}{$\begin{array}{c}\text { Cervicalgia after } \\
\text { corpectomy }\end{array}$} \\
\hline \multirow{2}{*}{$2.0 \pm 1.7$} & $\begin{array}{c}6-12 \\
\text { months }\end{array}$ & $\begin{array}{c}>24 \\
\text { months }\end{array}$ & \multirow{2}{*}{$1.9 \pm 1.3$} & $\begin{array}{c}6-12 \\
\text { months }\end{array}$ & $\begin{array}{c}>24 \\
\text { months }\end{array}$ \\
\cline { 2 - 3 } \cline { 5 - 6 } & $4.0 \pm 2.4$ & $4.0 \pm 2.9$ & & $2.9 \pm 1.5$ & $3.7 \pm 1.8$ \\
\hline
\end{tabular}

Comparative analysis shows high efficiency of both methods. In the laminoplasty group, there was a clear tendency for a significant neurological improvement in patients with moderate or severe manifestations of the disease. Improvement of the overall neurological status after surgery achieved in both groups was similar, as was the severity of the pain syndrome in a later (over 2 years) postoperative period. The length of stay for laminoplasty was from 5 to 20 days $(7.0 \pm 2.9)$, which is 2.5 days more than for corpectomy.

According to our experience and the literature data, indications for laminoplasty are as follows: clinical symptoms of spondylogenic myelopathy, the presence of three or more levels of compression, lordosis preservation, absence of segmental instability signs, inability to perform an anterior decompression, and age over 55 years. Contraindications are: signs of segmental instability, kyphotic deformity, untreatable comorbidities, presence of functional disorders of the nervous system, a mental illness in the anamnesis. ${ }^{19-21}$

The most common complication of laminoplasty is paresis of the muscles innervated by $\mathrm{C} 5$ roots (8.8\%). To prevent this, we introduced the practice of bilateral C4-C5 foraminotomy. Laminoplasty can be performed to save the support function of the vertebral column after removal of extensive cervical tumors. It is acceptable to use laminoplasty in cases of dorsal one-level stenosis.

It appears that a long history of the disease and a severe neurological deficit (the last stage of Nurick scale and $<8$ on the JOA scale) are also contraindications for laminoplasty with simultaneous C4-C5 foraminotomy. On the other hand, laminoplasty can be a complement to cervical spine operations performed from the posterior approach (removal of intra- or extramedullary tumors, DREZ operations, as well as a single-level isolated posterior stenosis).

Thus, our study shows the efficacy of laminoplasty with simultaneous foraminotomy in the surgical treatment of patients with CSM. We clarified the indications for implementation of decompressive-plastic surgery in this category of patients, and the obtained data can be used in the clinical practice of central and regional neurosurgical hospitals.

\section{CONCLUSIONS}

Both laminoplasty and corpectomy with consecutive stabilization are effective in surgical treatment of CSM. Significant neurological improvement is achieved in patients with moderate or severe manifestations of the disease. Severity of the pain syndrome in a later postoperative period is similar after laminoplasty and corpectomy surgery. Laminoplasty technique is preferred where there are clinical symptoms of spondylogenic myelopathy, presence of three or more levels of compression, preservation of lordosis, absence of segmental instability signs or kyphotic deformity, and inability to perform an anterior decompression. Laminoplasty can also be used in cases of dorsal one-level stenosis.

Bilateral C4-C5 foraminotomy is suggested to prevent C5-roots paresis after laminoplasty. But laminoplasty with simultaneous C4-C5 foraminotomy should not be performed in cases of long history of the disease and severe neurological deficit.

Outcomes of the data show a decreased risk of surgery complications compared to the anterior approaches. Meanwhile, axial pain in the early postoperative period is slightly stronger than in the corpectomy group, due to the less rigid fixation.

Improvements in proprioception and tactile sensitivity should be evaluated within the first 6 months after laminoplasty surgery. Our evidence suggests that laminoplasty is most effective at moderate and severe stages of proprioception deterioration.

Adequate selection of patients, based on the evaluation of clinical symptoms, extension of stenosis, neurological signs, and neuroimaging features enable excellent results to be achieved.

All authors declare no potential conflict of interest related to this article. 
CONTRIBUTION OF THE AUTHORS: Each author made significant individual contributions to this manuscript. MD (0000-0002-7839-309X)*, SA (0000-0003-4809-4117)* and DP (0000-0001-9588-7721)* were the main contributors in the drafting of the manuscript. MD, SA and DP performed the surgery, followed up patients and gathered clinical data. MD, SA and DP evaluated the data from the statistical analysis. AG (0000-0003-3451-5750)*, AK (0000-0001-7681-3073)*, AV (0000-0002-8006-1334)* and EP (0000-0001-9208-2987)* performed the literature search and review of the manuscript, and contributed to the intellectual concept of the study. ${ }^{*} \mathrm{ORCID}$ (Open Researcher and Contributor ID).

\section{REFERENCES}

1. Belova AN. Neyroreabilitatsiya: rukovodstvo dlya vrachey. 2-e izd. [Neurorehabilitation: guide for doctors. $2^{\text {nd }}$ edition]. Moscow: Antidor. 2002. (In Russ.)

2. Uotkins RG. [Predicting the outcomes of surgical treatment in patients with chronic disability due to pain in the lumbar spine]. Vestnik travmatologii i ortopedii im. NN Priorova. 2002;3:58-65. (In Russ.)

3. Matz PG, Anderson PA, Holly LT, Groff MW, Heary RF, Kaiser MG et al. The natural history of cervical spondylotic myelopathy. J Neurosurg Spine. 2009;11(2):104-11.

4. Dreval' MD, Gushcha Ao. [Surgical treatment of cervical spondylotic myelopathy using the method of laminoplasty: a review of the literature]. Hirurgiya pozvonochnika. 2015;12:44-50. (In Russ.)

5. Yusupov, MN. [Comparative analysis of structural and functional manifestations of cervical spondylotic myelopathy before and after decompressive operations]. Avtoreferat dis.... kand. med. nauk. Saint-Petersburg; 2011:6-24. (In Russ.)

6. Clarke E, Robinson PK. Cervical myelopathy: a complication of cervical spondylosis. Brain. 1956;79(3):483-510.

7. Lees F, Turner JW. Natural History and Prognosis of Cervical Spondylosis. Br Med J. 1963;2(5373):1607-10.

8. Bohm PE, Fehlings MG, Kopjar B, Tetreault LA, Vaccaro AR, Anderson KK et al. Psychometric properties of the $30-\mathrm{m}$ walking test in patients with degenerative cervical myelopathy: results from two prospective multicenter cohort studies. Spine J. 2017;17(2):211-17.

9. Chung JY, Kim SK, Jung ST, Lee KB. Clinical adjacent-segment pathology after anterior cervical discectomy and fusion: results after a minimum of 10-year follow-up. The Spine Journal. 2014;14(10):2290-8.

10. Heller JG, Edwards CC, Murakami H, Rodts GE. Laminoplasty versus laminectomy and fusion for multilevel cervical myelopathy: an independent matched cohort analysis. Spine (Phila Pa 1976). 2001;26(12):1330-6.

11. Guscha AO, Dreval MD, Kireeva NS, Korepina OS, Arestov SO, Petrosyan DV et al.
Laminoplasty and corporectomy in the treatment of spondylotic cervical myelopathy. Annals of clinical and experimental neurology. 2017;11(4):34-41. (In Russ.)

12. Hale JJ, Gruson KI, Spivak JM. Laminoplasty: a review of its role in compressive cervical myelopathy. Spine J. 2006;6(6 Suppl):289S-98.

13. Klement MR, Kleeman LT, Blizzard DJ, Gallizzi MA, Eure M, Brown CR. C5 palsy after cervical laminectomy and fusion: does width of laminectomy matter? Spine J. 2016;16(4):462-7.

14. Haddas R, Ju KL, Patel S, Arakal RG, Boah A, BelangerTA. Effect of Cervical Decompression Surgery on Gait in Adult Cervical Spondylotic Myelopathy Patients. The Spine Journal. 2017;17(10):S135.

15. Hirabayashi K, Watanabe K, Wakano K, Suzuki N, Satomi K, Ishii Y. Expansive open-door laminoplasty for cervical spinal stenotic myelopathy. Spine (Phila Pa 1976). 1983;8(7):693-9.

16. Lesoin F, Bouasakao N, Cama A, Servato R, Jomin M. [Role of surgical decompression by the anterior approach in myeloradiculopathies caused by cervical arthrosis. Apropos of 850 cases]. Sem Hop. 1983;59(39):2669-77. (In French)

17. Oyama M, Hattori S, Moriwaki N. A new method of cervical laminectomy. Chubu Nippon Seikeisaigaigeka. Gakkai Zasshi (Central Jpn J Orthop Traumatol). 1973;16:792-4.

18. Doita M, Sakai H, Harada T, Nishida K, Miyamoto H, Kaneko T et al. The influence of proprioceptive impairment on hand function in patients with cervical myelopathy. Spine (Phila Pa 1976). 2006;31(14):1580-4.

19. Derenda M, Kowalina I. [Cervical laminoplasty - review of surgical techniques, indications, methods of efficacy evaluation, and complications]. Neurol Neurochir Pol. 2006;40(5):42232. (In Polish)

20. Li Q, Kong Q, Zhang L, Sun T, Li T, Gong $Q$ et al. [Discussion of surgical indications for posterior expansive open-door laminoplasty extended to $\mathrm{C} 1$ level.] Zhongguo Xiu Fu Chong Jian Wai Ke Za Zhi. 2013;27(10):1214-20. (In Chin).

21. Yoshida M, Tamaki T, Kawakami M, Hayashi N, Ando M. Indication and clinical results of laminoplasty for cervical myelopathy caused by disc herniation with developmental canal stenosis. Spine (Phila Pa 1976). 1998;23(22):2391-7. 